\title{
Structure Force Analysis for Concrete Single Curved Arch Dam of Shuangchong Reservoir
}

\author{
Ji Dongyu \\ Hunan Urban Construction College \\ Xiangtan, China \\ hnjdy@126.com
}

\author{
Song Chuncao \\ North China University of Water Resources and \\ Electric Power \\ Zhengzhou, China \\ 285893543@qq.com
}

\begin{abstract}
Arch dam is a beautiful engineering structure, it has good mechanical properties, it is widely used in water conservancy engineering, in order to have a clear understanding for mechanical characteristics of arch dam structure. Using the finite element method for concrete arch dam of shuangchong reservoir gives simulation analysis, and the arch stress, deformation distribution in the course of construction and operation. The results show that a reasonable for concrete arch structure of shuangchong reservoir to meet the design requirements. Research for the design and construction of concrete single curved arch structures provide some reference. The results showed that, concrete single curved arch dam of Shuangchong reservoir is reasonable and feasible, arch dam's maximum tensile stress value appear junction of arch dam and bedrock, most of the stress values are smaller, stress and displacement values can meet engineering requirements.
\end{abstract}

Keywords-Shuangchong reservoir; Single curved arch; Force analysis; Stress distribution; Finite element method.

\section{ENGINEERING SITUATION}

Shuangchong Reservoir is located in Mian River tributary of Liuyang County, Hunan Province, which is a reservoir to generate electricity, combined with irrigation water resources and hydropower engineering. It works by dams, two dams, power plants and other buildings. Dams normal water level is $60.80 \mathrm{~m}$.Maximum height is $13.6 \mathrm{~m}$. Check flood dam is $12.6 \mathrm{~m}$.Design water level is $11.6 \mathrm{~m}$ and dead water level is $9.8 \mathrm{~m}$. Tail level is $2.2 \mathrm{~m}$. Dam is a narrow V-shaped valleys, single concrete arch dam, dam thicker than 0.15 .

\section{ARCH CALCULATION MODEL}

\section{A Model Parameters}

The concrete arch dam of Shuangchong reservoir uses the concrete strength class $\mathrm{C} 15$,elastic modulus $E_{1}=22 \mathrm{GPa}$, poisson's ratio $\mu_{1}=0.167$ [1-2].

Bulk density $\gamma_{1}=24 \mathrm{kN} / \mathrm{m}^{3}$. Dam valley sides hillside slope approximation 1:1,dam good geological conditions, exposed bedrock, fresh, intact hard rock for Banxi group sandy slate and quartz sandstone.Rock elastic modulus $E_{2}=18 \mathrm{GPa}$, Poisson's ratio $\mu_{2}=0.28$.

\section{B Model Element}

Concrete arch dam and bedrock structure model uses 8-node isoparametric block element. The element is applied to three-dimensional model entity structure,has plasticity,creep,swelling,stress stiffening,large deformation and large strain properties, the element has eight nodes and each node has three translational degrees of freedom[3-5]

\section{Model Size}

The size of the entire calculation model is down the river to fetch $65 \mathrm{~m}$,perpendicular to the direction of the river to take $55 \mathrm{~m}$, vertical take $33.6 \mathrm{~m}$, simulation range model is $65 \mathrm{~m} \times 55 \mathrm{~m} \times 33.6 \mathrm{~m}[6-7]$. Arch and rock element division shown in Fig .1 .

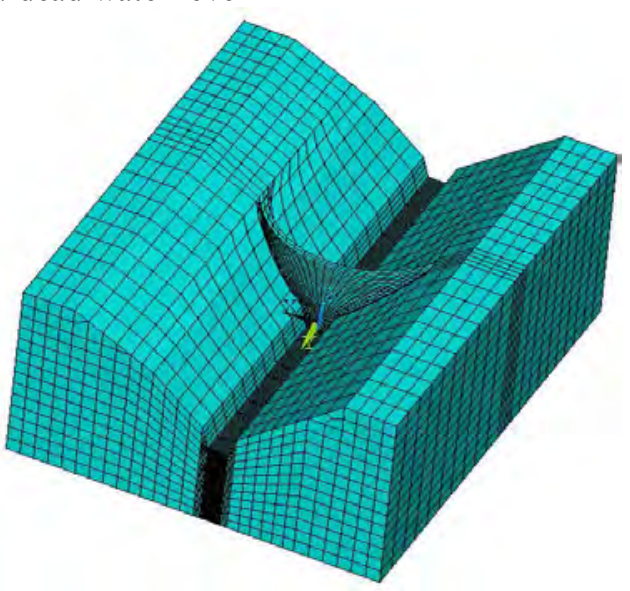

Figure 1. Arch and bedrock FEM division 


\section{Calculation Condition}

Considering the arch structure during operation of the mechanical characteristics[8-9], the main consideration of the following three kinds of calculation condition is that casel(dead water level and weight),case2(design water level and tail water level and weight),case3(check flood level and tail water level and weight).

TABLE I. EACH CONDITION OF ARCH DAM SECTIONAL CROWN STRESS ON KEY POINTS(MPA)

\begin{tabular}{|c|c|c|c|c|c|c|c|c|c|c|}
\hline \multicolumn{3}{|c|}{ Location } & (1) & (2) & (3) & (4) & (5) & (6) & (7) & (8) \\
\hline \multirow{4}{*}{ Case 1} & \multirow{2}{*}{$\begin{array}{c}\text { Upstream } \\
\text { face }\end{array}$} & Circumferential stress & -0.01 & -0.12 & -0.14 & -0.26 & -0.23 & -0.14 & -0.07 & -0.04 \\
\hline & & Longitudinal stress & -0.04 & -0.08 & -0.07 & -0.26 & -0.24 & -0.12 & -0.04 & -0.05 \\
\hline & \multirow{2}{*}{$\begin{array}{l}\text { Downstrea } \\
\text { m face }\end{array}$} & Circumferential stress & -0.01 & 0.12 & 0.05 & 0.10 & 0.04 & -0.01 & -0.02 & -0.03 \\
\hline & & Longitudinal stress & -0.24 & -0.11 & -0.15 & 0.03 & 0.05 & -0.02 & -0.04 & -0.07 \\
\hline \multirow{4}{*}{ Case 2} & \multirow{2}{*}{$\begin{array}{c}\text { Upstream } \\
\text { face }\end{array}$} & Circumferential stress & -0.01 & -0.15 & -0.17 & -0.40 & -0.43 & -0.34 & -0.22 & -0.14 \\
\hline & & Longitudinal stress & 0.01 & -0.03 & 0.03 & -0.26 & -0.35 & -0.24 & -0.08 & -0.05 \\
\hline & \multirow{2}{*}{$\begin{array}{l}\text { Downstrea } \\
\text { m face }\end{array}$} & Circumferential stress & -0.01 & 0.15 & 0.08 & 0.19 & 0.11 & 0.03 & -0.01 & 0.01 \\
\hline & & Longitudinal stress & -0.28 & -0.15 & -0.23 & 0.04 & 0.16 & 0.10 & -0.01 & -0.01 \\
\hline \multirow{4}{*}{ Case 3} & \multirow{2}{*}{$\begin{array}{c}\text { Upstream } \\
\text { face }\end{array}$} & Circumferential stress & -0.01 & -0.18 & -0.20 & -0.57 & -0.69 & -0.65 & -0.54 & -0.44 \\
\hline & & Longitudinal stress & 0.08 & 0.04 & 0.16 & -0.20 & -0.40 & -0.35 & -0.16 & -0.01 \\
\hline & \multirow{2}{*}{$\begin{array}{c}\text { Downstrea } \\
\text { m face }\end{array}$} & Circumferential stress & -0.01 & 0.19 & 0.12 & 0.30 & 0.19 & 0.04 & -0.04 & -0.06 \\
\hline & & Longitudinal stress & -0.31 & -0.19 & -0.32 & 0.02 & 0.23 & 0.21 & 0.08 & -0.01 \\
\hline
\end{tabular}

As can be seen from Table 1, the three conditions, the stress on the upstream face and the downstream face Arch relatively low, does not exceed the tensile strength of concrete $\mathrm{C} 15$, the design value of the compressive strength,to meet the strength requirements.

\section{A Stress Analysis}

Through the stress analysis for the concrete arch dam of shuangchong reservoir, calculated the various conditions of arch dam sectional crown stress on key points, the stress calculation results shown in Table 1.

To more clearly in the operating conditions arch overall stress distribution, Fig .2 through Fig .5 shows the main arch under stress case 2,the circumferential stress and vertical stress contour map. 


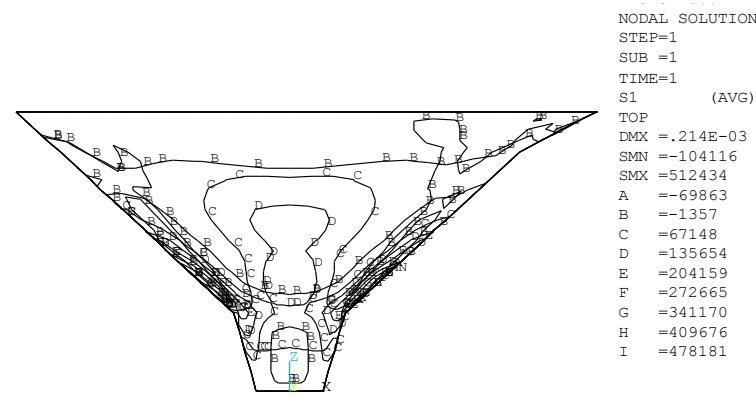

Figure 2. The arch's the first principal stress contour map under case $2(\mathrm{~Pa})$

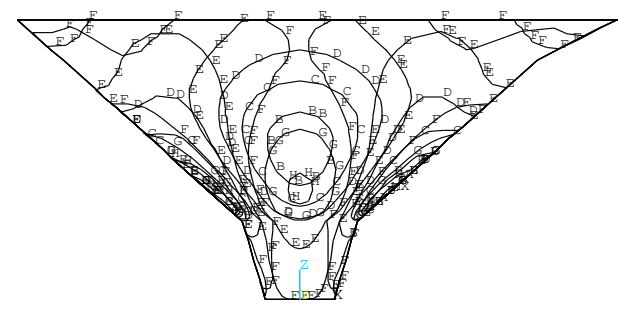

Figure4. The arch's the circumferential stress contour map under case $2(\mathrm{~Pa})$

As can be seen from Fig .2 to Fig .5, Arch lower overall principal stress value, the larger the principal tensile stresses are present in the interface between the arch and the bedrock, which is mainly due to the phenomenon here that is caused by the stress concentration and cell division is smaller,so that stress concentration here is more obvious. For high arch design, when a higher stress value here,can be used finite element equivalent stress method[10] to reduce the

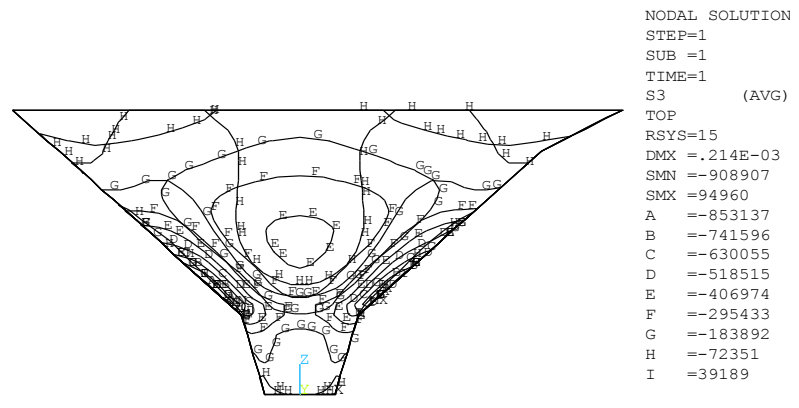

Figure 3. The arch's the third principal stress contour map under case $2(\mathrm{~Pa})$

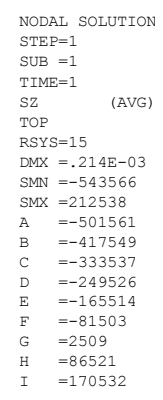

Figure5. The arch's the vertical stress contour map under case $2(\mathrm{~Pa})$

stress value here, getting the FEM results can be used to guide the arch design.

\section{B Deformation Analysis}

By deformation analysis of shuangchong reservoir concrete arch dam,calculated each condition of arch dam sectional crown radial displacement values on key points, the stress calculation results shown in Table 2.Under the arch contour displacement condition is shown in Fig .6 and Fig .7.

TABLE II. EACH CONDITION OF ARCH DAM RADIAL DISPLACEMENT SECTIONAL CROWN ON KEY POINTS

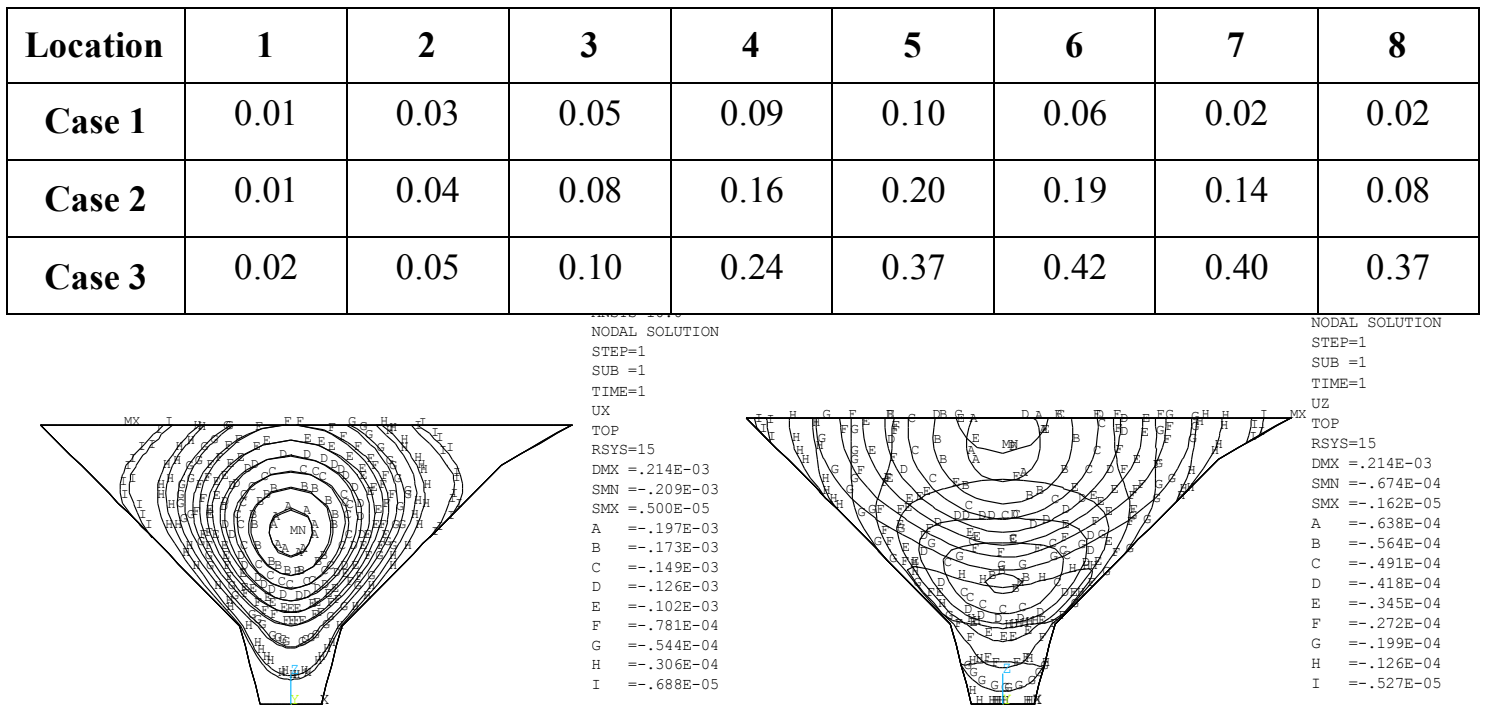

Figure6. The arch's the radial displacement contour map under case $2(\mathrm{~m})$
Figure 7. The arch's the vertical displacement contour map under case $2(\mathrm{~m})$ 
From Table 2 and Fig .6 and Fig .7 can be seen that the maximum radial displacement of the arch appears in the middle of the crown, the maximum vertical displacement occurs at the top of the arch dam crown. Lower overall displacement arch structure to meet the engineering requirements.

\section{CONCLUDING REMARKS}

Through the concrete arch dam of shuangchong reservoir stress and deformation analysis indicates that the reservoir using concrete arch structure is reasonable and practicable and the stress and displacement calculations can meet the engineering requirements.

\section{REFERENCES}

[1] SL191-2008. Design Code for Hydraulic Concrete Structure[S]. China Water Conservancy and Hydropower Press, 2008.

[2] Bans Sevim,Ahmet Can Altunisik,Alemdar Bayraktar et al. Estimation of Elasticity Modulus of a Prototype Arch Dam Using Experiments" Methods [J]. Journal of Materials in Civil Engineering,2012,24(4):321-329.

[3] Xucheng Wang. Finite Element Method [M]. Tsinghua University Press, 2003.
[4] Bofang Zhu. Finite Element Method Principle and Application [M]. China Water Conservancy and Hydropower Press, 1998.

[5] Bans Sevim,Ahmet Can Altunisik,Alemdar Bayraktar et al. Earthquake Behavior of Berke Arch Dam Using Ambient Vibration Test Results [J]. Journal of Performance of Constructed Facilities,2012,26(6):780-792.

[6] Khaled H. Bayagoob,Jamaloddin Noorzaei,Aeid A. Abdulrazeg et al. Coupled thermal and structural analysis of roller compacted concrete arch dam by three-dimensional finite element method [J]. Structural engineering and mechanics,2010,36(4):401-419.

[7] Li Shouyi,Ding Lujun,Zhao Lijuan et al. Optimization design of arch dam shape with modified complex method [J]. Advances in Engineering Software,2009,40(9):804-808.

[8] Shanding Ma, Ruze Wang. Hydropower Station Structures (The Second Edition) $[\mathrm{M}]$. China Water Conservancy and Hydropower Press, 1996.

[9] Bans Sevim,Alemdar Bayraktar,Ahmet Can Altunisik et al. Investigation of water length effects on the modal behavior of a prototype arch dam using operational and analytical modal analyses $[\mathrm{J}]$ Structural engineering and mechanics,2011,37(6):593-615.

[10] Bofang Zhu, Jizhang Gao, Zuyu Chen, Yisheng Li. Arch Dam Design and Research $[\mathrm{M}]$. China Water Conservancy and Hydropower Press, 2002. 